doi:10.32620/oikit.2018.81.13

УДК 658.58:004.67:621.395.721.5

У.І. Аніканова-Широкова

\title{
Методика оцінювання якості послуг ремонту високотехнологічних пристроїв
}

\author{
Національний аерокосмічний університет ім. М. Є. Жуковського \\ «Харківський авіаційний інститут»
}

\begin{abstract}
Визначено критерії оцінювання якості послуг ремонту, розроблено двоетапну методику оцінювання якості послуги ремонту, яка складається з технічного контролю та опитування. Автором розроблено анкету опитування. Виявлено наслідки проведення оптимізації.

Ключові слова: якісна послуга ремонту, критерії оцінювання якості послуг ремонту, оцінювання задоволеності.
\end{abstract}

\section{Вступ}

Кожен із нас є заручником науково-технічного прогресу. Нові технології, зручна у використанні техніка, гаджети дозволяють не тільки розважатися, знаходити нові знайомства, кохання, але й допомагають у самовдосконаленні, отриманні освіти. Кожен може у будь-яку хвилину перенестися в інший куточок планети, поринути у подорож країнами та навіть відвідати космос.

Діти XXI сторіччя - це діти, які «народилися» із технологіями в руках. Із самого їх дитинства технології всюди - відеоняня, контролер дитячого сну, смартфон батьків, тварини-роботи. Сучасна людина так чи інакше залежить від техніки. Але техніці, як і кожній речі, властиво виходити з ладу.

Профресійна та своєчасна діагностика дозволяє виявити та вирішити проблему, що зменшує життєвий цикл пристрою.

Варто зрозуміти, що якісна послуга - це сукупність характеристик, що підтверджують відповідність наданої допомоги потребам замовника, його очікуванням, сучасному рівню науки та технологій. Іншими словами, це та послуга, яка може задовольнити потреби і початкові очікування споживача, а також спонукати останнього скористатися даною послугою повторно.

На жаль, в Україні не існує критеріїв, за якими можна було б оцінити якість наданої послуги. Відповідно, якщо немає способу провести оцінювання якості, якості не дотримуються.

Періодична перевірка стану технологічного обладнання, вимірювальних приладів на робочих місцях і кваліфрікації співробітників, а також своєчасне проведення опитування замовників дозволять оцінити та підвищити якість надання послуг.

\section{Оцінювання якості послуг ремонту високотехнологічних пристроїв}

Оцінювання якості надання послуг ремонту високотехнологічних пристроїв має складатися із двох напрямів: технічного контролю і опитування.

Основними завданнями технічного контролю в наданні послуг ремонту, налаштування i оптимізації високотехнологічних пристроїв мають бути: забезпечення високої якості наданих послуг, надійності пристроїв, що здаються в 
експлуатацію, та виключення можливості оплати робіт, виконаних незадовільно або не виконаних взагалі.

Технічний контроль якості виконаних робіт з ремонту високотехнологічних пристроїв складається з таких етапів:

- вхідного контролю;

- д діагностичного контролю;

- контролю закупівлі;

- вихідного контролю;

- підсумкового контролю.

Вхідний контроль виконують під час прийому пристрою. Майстер перевіряє зовнішній стан техніки та ії фрункціонал, робить висновки про наявність певних проблем і дефектів зі слів замовника та реєструє це в акті прийому-передачі товару, договорі на надання послуги.

Діагностичний контроль відбувається за допомогою спеціального обладнання (мультиметра, осцилографа, лабораторного блока живлення та ін.). Цей вид контролю допомагає точно визначити проблему та розробити план дій для усунення недоліку.

Контроль закупівлі - перевірка працездатності деталей та стану витратних матеріалів, потрібних для надання послуги.

Вихідний контроль проводять після виконання роботи майстром. Цей вид контролю здійснюють у чотири етапи:

1) перша візуальна перевірка якості загального складання (комплектність, правильність сполучення та взаємодії всіх вузлів, якість оброблення поверхонь і т. iн.); функцій;

2) перевірка працездатності пристрою, а також його основних і додаткових

3) друга (повторна) візуальна перевірка якості загального складання пристрою;

4) перевірка відповідності зовнішнього стану пристрою після проведеної роботи, зазначеної в документації.

Підсумковий контроль виконується замовником послуги разом із майстром за допомогою повторної перевірки працездатності пристрою, а також його повного функціоналу, огляду зовнішнього стану, наявності наданих послуг відповідно до акту виконаних робіт або договору.

Для поліпшення якості надання послуг ремонту необхідно впровадження критеріїв оцінювання якості. Це дозволить побачити реальну ситуацію завдяки оцінюванню населення і знайти методи поліпшення якості.

Розглянемо можливі принципи управління якістю, а саме проведення незалежного оцінювання якості надання послуг сервісними установами. Оцінювання необхідно проводити в сервісних установах за такими критеріями:

- відкритість і доступність інфрормації про організацію;

- комфрортність і доступність отримання послуг (місцезнаходження, вартість та ін.);

- час очікування;

- доброзичливість, ввічливість, компетентність працівників (профресійна придатність);

- задоволення наданими послугами;

- надання послуги відповідно до обумовлених строків. 
Оцінювання може бути проведено за допомогою таких методів: та ін.);

1) спостереження (перевірка сервісних організацій, кваліфрікації працівників

2) опитування (анкетування пацієнтів і медичних працівників).

Для вдосконалення порівняння показників якості використовують статистичні методи.

Здійснити оцінювання якості надання послуг ремонту зможуть:

- замовники, заповнюючи інтерактивну анкету на офріційних сайтах організацій або на паперовому носії;

- особи-аудитори.

Якщо оцінювати якість надання послуг ремонту високотехнологічних пристроїв у даний момент, то можна виявити ряд недоліків:

- некомпетентність, некваліфрікованість майстрів;

- застаріле обладнання;

- недотримання обумовлених строків;

- невиконання зобов'язань ремонту внаслідок настання гарантійного випадку.

На жаль, внаслідок відсутності нормативно-правової бази для здійснення контролю надання послуг ремонту високотехнологічних пристроїв споживачі все частіше потрапляють у ситуації, коли не можуть відстояти свої права на отримання якісної послуги.

Найменше, що можна зробити для поліпшення якості, - створити ефективну методику, яка дозволяє розробляти і вдосконалювати способи оцінювання якості. Необхідно домогтися інтеграції зусиль щодо оцінювання якості в роботу, спрямовану на вдосконалення обслуговування, - як у кожному окремому закладі, так і в більш широкому масштабі.

Об'єктивно оцінити якість надання послуг можна, використовуючи бальний спосіб оцінювання (таблиця). При бальному способі оцінювання якості кожен критерій оцінюється певною кількістю балів, після чого результати підсумовують. Сума всіх балів виражає загальну оцінку послуги. Послугу ремонту умовно можна розділити на три етапи: 1-й етап - ініціалізація послуги (планування, ознайомлення і вибір), 2-й етап - надання послуги (супровід етапу надання послуги), 3-й етап завершення надання послуги (супровід етапу завершення надання послуги). Якість надання послуг запропоновано оцінювати за стобальною системою: 1-й етап - 41 бал, 2-й етап - 39 балів, 3-й етап - 20 балів.

Оцінку «відмінно» встановлюють при виконанні всіх основних і додаткових вимог.

Оцінку «добре» встановлюють при виконанні всіх основних і часткового виконання (не менше 50\%) додаткових вимог.

Оцінку «задовільно» встановлюють при виконанні всіх основних і часткового виконання (менше 50\%) додаткових вимог.

Оцінку «незадовільно» встановлюють при невиконанні однієї або більше 3 основних вимог.

Висока якість надання послуги оцінюється загальною кількістю балів від 82 до 100. 
Открытые информационные и компьютерные интегрированные технологии № 81, 2018

Таблиця

Оцінювання задоволеності замовників наданими послугами ремонту

\begin{tabular}{|c|c|c|}
\hline $\begin{array}{l}\text { № } \\
\Pi / \Pi\end{array}$ & Критерій & Оцінка, бал \\
\hline \multicolumn{3}{|c|}{ 1-й етап - Ініціалізація послуги } \\
\hline 1 & Наявність сайту & \multirow{10}{*}{$\begin{array}{c}\text { Так }-2 \\
\text { ні }-0\end{array}$} \\
\hline 2 & Відгуки та рекомендації клієнтів & \\
\hline 3 & Контактна інформація & \\
\hline 4 & Графрік роботи & \\
\hline 5 & Наявність реклами & \\
\hline 6 & Наявність системи знижок & \\
\hline 7 & Наявність транспортної розв'язки поблизу & \\
\hline 8 & Наявність ліцензії, патенту, сертифіката на обслуговування & \\
\hline 9 & Наявність реалізації сумісних товарів & \\
\hline 10 & Наявність прайсу & \\
\hline 11 & Асортимент сумісних товарів & \multirow{3}{*}{$\begin{array}{c}\text { Низька - } 1 \\
\text { Середня - } 2 \\
\text { Висока - } 3 \\
\end{array}$} \\
\hline 12 & Багатофункціональність сервісу (спектр надання послуг) & \\
\hline 13 & Конкурентоспроможність & \\
\hline 14 & Якість, повнота та доступність інфоормації про заклад & \multirow{3}{*}{$\begin{array}{c}\text { Відмінно - } 3 \\
\text { Добре - } 2 \\
\text { Задовільно - } 1 \\
\text { Незадовільно - } 0 \\
\end{array}$} \\
\hline 15 & Місцезнаходження & \\
\hline 16 & Доступність отримання послуги & \\
\hline 17 & Вартість послуг & $\begin{array}{c}\text { Низька - } 3 \\
\text { Середня - } 2 \\
\text { Висока - } 1\end{array}$ \\
\hline \multicolumn{3}{|c|}{ 2-й етап - Надання послуги } \\
\hline 1 & Ввічливе ставлення персоналу & \multirow{7}{*}{$\begin{array}{c}\text { Відмінно - } 3 \\
\text { Добре - } 2 \\
\text { Задовільно - } 1 \\
\text { Незадовільно - } 0\end{array}$} \\
\hline 2 & Час очікування & \\
\hline 3 & Розуміння проблеми & \\
\hline 4 & Швидкість обслуговування & \\
\hline 5 & Своєчасність надання послуги & \\
\hline 6 & Компетентність і кваліфікованість персоналу & \\
\hline 7 & Повнота (комплексність) діагностики & \\
\hline 8 & Надання послуги згідно з обумовленими строками & \multirow{8}{*}{$\begin{array}{c}\text { Так }-2 \\
\mathrm{Hi}-0\end{array}$} \\
\hline 9 & Надання договору на послугу сервісною установою & \\
\hline 10 & Наявність безкоштовної діагностики & \\
\hline 11 & Надання гарантії на виконану роботу & \\
\hline 12 & Можливість надання послуги (ремонту) у присутності замовника & \\
\hline 13 & Наявність камер відеоспостереження & \\
\hline 14 & Наявність бездротової мережі Wi-Fi & \\
\hline 15 & Надання можливості перевірки роботи пристрою/товару & \\
\hline 16 & $\begin{array}{l}\text { Надання додаткових послуг (налаштування, перенос даних, } \\
\text { оптимізація та ін.) }\end{array}$ & Так -2 ні -0 \\
\hline \multicolumn{3}{|c|}{ 3-й етап - Завершення надання послуги } \\
\hline 1 & Задоволеність поясненнями щодо проведеної діагностики & Відмінно - 3 \\
\hline 2 & Задоволеність швидкістю виявлення майстром проблеми & Добре - 2 \\
\hline 3 & Задоволеність швидкістю вирішення проблеми & Задовільно - 1 \\
\hline 4 & Задоволеність результатом & Незадовільно - 0 \\
\hline 5 & $\begin{array}{c}\text { Виконання безкоштовного ремонту у разі поломки пристрою у } \\
\text { гарантійний термін внаслідок гарантійного випадку }\end{array}$ & \multirow{4}{*}{$\begin{array}{l}\text { Так }-2 \\
\text { нi }-0\end{array}$} \\
\hline 6 & Рекомендували б Ви вибраний сервісний центр? & \\
\hline 7 & Рекомендували б Ви вибраного майстра? & \\
\hline 8 & $\begin{array}{c}\text { Наявність бажання повторно скористатися послугою вибраного } \\
\text { спеціаліста у вибраній установі }\end{array}$ & \\
\hline
\end{tabular}




\section{Висновки}

Проведення оцінювання за наведеними вище критеріями допоможе:

- підвищити якість надання послуг ремонту;

- створити рейтинг сервісних установ; інформації;

- полегшити вибір сервісної установи та майстра шляхом надання повної

- дізнатися про реальні недоліки та переваги обслуговування;

- створити інформаційну платформу;

- захистити споживача та майстра від помилок і махінацій.

\section{Список літератури}

1. Салухіна Н.Г. Стандартизація та сертифікація товарів і послуг.: підручник /Н.Г. Салухіна, О.М. Язвінська - К.: Центр учбової літератури, 2010. - 336 с.;

2. Сирохман І.В. Управління якістю.: навч. посібник /І.В. Сирохман, Т. М. Лозова, О.Я. Давидович, М. -М. В. Калимон - Львів.: видавництво «Растр-7», 2015. $-428 \mathrm{c}$.

Поступила в редакцию 27.09.2018

\section{Методика оценивания качества услуг ремонта высокотехнологических устройств}

Определены критерии оценивания качества услуг ремонта, разработана двухэтапная методика оценивания качества услуги ремонта, которая состоит из технического контроля и опроса. Автором разработана анкета опроса. Определены последствия проведения оптимизации.

Ключевые слова: качественная услуга ремонта, критерии оценивания качества услуг ремонта, оценка удовлетворенности.

\section{Methodology of assessing the quality of repair services of high-tech devices}

Has been identified criteria for assessing the quality of repair services, has been developed a two-stage methodology for assessing the quality of repair services, which consist of technical control and survey. The author has developed a survey questionnaire. Has been identified the effects of optimization.

Key words: quality of repair services, criteria for assessing the quality of repair services, assessment of satisfaction.

\section{Сведения об авторах:}

Аніканова-Широкова Уляна Ігорівна - студент 159а групи кафр. 106 “Хімії, екології та експертизних технологій”, Національний аерокосмічний університет ім. М. Є. Жуковського “Харківський авіаційний університет”, Україна. 